\title{
Pengaruh Likuiditas, Profitabilitas, dan Free Cash Flow Pada Kebijakan Dividen (Studi Pada BUMN Tahun 2015-2019)
}

\author{
Rizky Agustin ${ }^{1}$, Fatchur Rochman ${ }^{2}$ \\ ${ }^{1}$ Mahasiswa Program Studi Akuntansi, Universitas Merdeka Madiun \\ ${ }^{1}$ E-mail: agustinrizky590@gmail.com \\ ${ }^{2}$ Program Studi Akuntansi, Universitas Merdeka Madiun \\ ${ }^{2}$ E-mail: fatchur@unmer-madiun.ac.id
}

\begin{abstract}
This research intend to decide the influence of liquidity, profitability and free cash flow (FCF) at dividend policy. The sampling technique untized was purposive sampling method. The secondary data were obtained from from the yearly report of 11 stateowned enterprises that were registered on the Indonesia Stock Exchange for 2015 - 2019. The multiple regression by the SPSS V-16.00 program was performed using for data analysis. The yield indicated that partly the liquidity and free cash flow variables did not had significant effect on dividend policy, the profitability variable had a significant effect on dividend policy. Simultaneously the variable ol liquidity, profitability and FCF indicated a significant effect on dividend policy at stateowned enterprises that are registered on the Indonesian Stock Exchange in 2015 - 2019.
\end{abstract}

Keywords: Liquidity, Profitability, Free Cash Flow, Dividend Policy.

\section{A. Latar Belakang}

\section{PENDAhuluan}

Dunia usaha terus berkembang dengan pesat mengikuti kompetisi yang semakin ketat ketat terjadi. Masing-masing korporasi harus mempunyai strategi jangka panjang dan jangka pendek untuk memenangkan persaingan. Strategi itupun harus senantiasa dievaluasi untuk mengembangkan strategi baru yang lebih adaptif dengan keinginan pelanggan. Secara umum tujuan perusahaan adalah mencari laba. Perusahaan yang sudah memperoleh laba diprioritaskan guna dibelanjakan ulang pada harta operasi guna pengembangan perusahaan, membayar hutang maupun dibagi pada pemilik saham.

Menurut Trisna \& Gayatri (2019) dalam Prastya (2019) menerangkan bahwa guna mendapatkan kemakmuran company juga para pemilik saham, dibutuhkan aturan-aturan yang bisa menyeimbangkan keperluan company juga pemilik saham. Ketentuan aturan dividen merupakan salah satu yang sangat penting harus dipikirkan dengan tepat sebab terkait dengan kepentingan dari banyak pihak.

Dividen adalah kompensasi yang diterima oleh pemilik saham, selain capital gain (Hanafi, 2018: 361). Pelaksanaan pembagian dividen, investor mengharapkan dividen dibagi secara stabil, sebab dividen yang dibagi secara stabil bisa membangun trust investor pada company. Manajemen company harus bisa mengoptimalkan ketentuan kebijakan dividen, supaya dapat terwujud balancing pembagian dividen saat ini dan growth di masa depan. Maka perusahaan harus mempelajari banyak variabel yang bisa mempengaruhi ketentuan pembagian dividen secara tepat. Problem kebijakan dividen terdapat pada Non-BUMN maupun BUMN. Besarnya dividen ditentukan RUPS.

BUMN ialah badan usaha milik negara di mana semua atau sebagian besar equity-nya dipunyai negara lewat penyertaan equity dengan langsung dari harta negara terpisah. Harta negara terpisah ialah kekayaan negara bersumber dari APBN khusus guna penyertaan modal negara untuk persero dan/atau Perum serta PT lainnya (UU No. 19 tahun 2003).

Variabel-variabel penentu kebijakan dividen berdasarkan pendapat Hanafi (2018:375) adalah likuiditas. Likuiditas yaitu kemampuan company dalam melunasi utang jangka pendek pada waktunya. Terdapat fenomena naik-turun pertumbuhan ekonomi Indonesia, yaitu pada tahun 2014 senilai 5,02\%, 2015 senilai 4,79\%, 2016 senilai 5,02\%, 2017 senilai $5,07 \%, 2018$ senilai $5,17 \%, 2019$ senilai 5,02\% (www.bps.go.id).

Terjadinya kasus fluktuasi pertumbuhan ekonomi, manajemen perusahaan memiliki tugas penting untuk tetap menstabilkan dividennya atau memenuhi kewajiban jangka pendeknya. Faktor yang kedua kebijakan dividen menurut Hanafi (2018:375) yaitu profitabilitas. Profitabilitas adalah gambaran sebuah company dalam mendapatkan profit. Fenomena ketidakstabilan kondisi ekonomi, manajemen perusahaan akan tetap menstabilkan dividennya atau menahan laba untuk investasi masa depan.

Variabel ketiga yang berdampak pada kebijakan dividen menurut Prastya (2019) ialah kas masuk bebas. Kas masuk bebas adalah deskripsi cash flow yang ada pada perusahaan, digunakan untuk biaya operasional dan biaya lainnya. Kas masuk 
bebas sekarang belum mendapatkan perhatian nyata oleh investor sebab company yang ada tidak mengutarakan data aliran kas masuk secara tersurat sehingga belum berdampak pada penerapan kebijakan dividen oleh company.

Masalah tersebut berkaitan dengan konflik keagenan. Masalah agensi yang ada pada agen dengan principal di antaranya terjadi disebabkan pihak principal khawatir apabila company mempunyai aliran kas masuk yang banyak akan ditempatkan untuk sumber daya non- efisien dan untuk investasi non-visible. Oleh karena itu, upaya memperkecil cost agency dampak munculnya masalah keagenan, maka agen melaksanakan tindakan pelunasan dividen pada pemilik saham.

Berdasarkan uraian di atas, riset sekarang bertujuan guna menguji apakah variabel likuiditas, profitabilitas, dan FCF mempengaruhi kebijakan dividen. Data penelitian adalah annual report dari BUMN Go Public tahun 2015-2019.

\section{B. Landasan Teori}

\section{Variabel-variabel berpengaruh pada kebijakan dividen}

1. Likuiditas

Likuiditas yaitu perbandingan yang mendeskripsikan kapasitas company dalam membayar short term debt (Kasmir, 2010:110). Maksudnya perusahaan sanggup melunasi kewajiban membayar utang jangka pendek yang jatuh tempo.

2. Profitabilitas

Profitabilitas ialah kapasitas company untuk menghasilkan profit guna melunasi short term debt dan long term debt, serta membayar dividen guna pemegang saham. Semakin banyak profit yang didapatkan, makin banyak dividen yang disalurkan pula.

3. FCF

Arus kas bebas ialah aliran cash yang mendeskripsikan banyaknya cash yang bisa didapatkan company pasca membelanjakan dana untuk mengembangkan hartanya (Guinan, 2010:131). Arus kas bebas begitu berarti bagi company sebab perusahaan bisa memanfaatkan opportuny guna membangun value pemegang saham. Laporan arus kas ialah laporan aktivitas investasi, pendanaan, serta operasi selama satu periode oleh perusahaan (Brigham dan Houstan, 2011:59).

\section{Kebijakan Dividen}

Dividen adalah kompensasi yang diperoleh oleh pemilik saham, selain capital gain (Hanafi 2018: 361). Besarnya dividen akan melambungkan nilai perusahaan serta dividen yang rendah akan menurunkan nilai perusahaan. Pendapat Riyanto (2010: 269), kebijakan dividen oleh perusahaan yaitu:

a. Kebijakan dividen stabil.

b. Kebijakan dividen melalui penetapan dividen paling sedikit ditambah tambahan tertentu.

c. Kebijakan dividen melalui penetapan dividen rasio pembayaran konstan.

d. Kebijakan dividen fleksibel.

\section{Agency Theory}

Pendapat Jensen and Meckling (1976) dikutip oleh Prastya (2019), agency theory yaitu koneksi kontrak keagenan di mana 1 atau lebih principal memakai agen yang diwakili manajemen guna melakukan kegiatan company. Principal memberikan fasilitas serta uang dan manajemen mengelola perusahaan. Konflik keagenan terjadi karena pemilik saham mengharapkan laba dibagi berupa dividen, sedangkan manajer mengharapkan profit ditahan guna pertumbuhan perusahaan ke depan.

\section{Signalling Theory}

Signalling theory timbul disebabkan adanya assymetric information antara pemilik saham dengan manajer (Tarwiyah, 2018). Hal ini terjadi karena informasi berat sebelah antara principal dan agen. Suatu perusahaan yang prospek keuangannya baik tidak akan memberitahukan sinyal informasi low-cost kepada pemilik saham. Sebab akan gampang dijiplak oleh perusahaan lain yang prospek keuangannya buruk. Tarwiyah (2018) menyampaikan bahwa assymetric informasi antara investor dengan manajemen, menjadikan pengumuman dividen payout adalah tanda tentang situasi saat ini dan masa depan.

\section{Hipotesis}

1. Pengaruh Likuiditas pada Kebijakan Dividen

Likuiditas adalah kapasitas company untuk menutup short term debt melalui seluruh aktiva lancar yang dipunyai perusahaan sebelum masa pinjaman berakhir. Company yang mempunyai likuiditas tinggi akan dapat mengatasi short term debt. Sehingga aset lancar yang banyak bisa untuk melunasi dividen. Hal ini didukung oleh penelitian Suyono (2018) yang mengemukakan, semakin banyak kas serta likuiditas company secara total menyebabkan semakin tinggi kapasitas perusahaan melunasi dividen. Tingkat likuiditas tinggi bisa mendeskripsikan kinerja company yang handal sebab tingkat likuiditas yang handal perusahaan menyebabkan semakin gampang melunasi pembayaran utang dividen.

$\mathrm{H}_{1}$ : Likuditas berpengaruh pada kebijakan dividen

2. Profitabilitas berpengaruh pada kebijakan dividen 
Profitabilitas adalah kapasitas company guna mengukur efektivitas pengelolaan company dalam mengurusi harta, penjualan serta capital yang dipunyai perusahaan guna mendapatkan profit untuk perusahaan. Banyaknya profitabilitas menunjukkan makin tingginya tingkat profit diperoleh perusahaan. Semakin besarnya profit perusahaan secara otomatis akan mendorong peningkatan sharing dividen pada pemilik saham. Kesimpulan ini sejalan dengan hasil riset Tarwiyah (2018), mengemukan profitabilitas tinggi akan berpengaruh pada kenaikan dividen dan dapat menunjukkan tanda kalau perusahaan dalam keaadaan bagus. Kecenderungan profitabilitas besar yang didapatkan perusahaan, berbanding lurus dengan sharing pembayaran deviden besar pada pemilik saham pula. Jadi. meningkatnya ROA perusahaan akan berdampak positif pada dividend payout ratio.

$\mathrm{H}_{2}$ : Profitabilitas mempengaruhi kebijakan dividen

3. FCF berpengaruh pada kebijakan dividen

FCF yaitu deskripsi arus cash milik perusahaan pasca dibebani biaya operasional serta pengeluaran lainnya. Dari arus kas bebas ini memberikan peluang pada perusahaan untuk meningkatkan nilai pemilik saham. Pernyataan tersebut seiring dengan riset Prasetio dan Suryono (2016) yang mengemukan bahwa perolehan FCF tinggi menyebabkan tambah besar pula rasio pembagian dividen. Sejalan dengan teori kontrak pada hipotesis, maka manajer akan membayarkan dividen ke pemilik saham yang besar guna menghindari overinvestment (masalah arrus kas bebas).

$\mathrm{H}_{3}$ : FCF berpengaruh pada kebijakan dividen

4. Pengaruh Likuiditas, Profitabilitas serta FCF secara silmutan pada Kebijakan Dividen

Likuiditas berjalan searah dengan kebijakan dividen. Likuiditas yang tinggi akan menyebabkan semakin tinggi kapasitas perusahaan dalam sharing dividen. Profitabilitas adalah perbandingan menilai kapasitas perusahaan dalam mencari profit (Kasmir 2010:110). Dan arus kas bebas yang besar menunjukkan kapasitas perusahaan membayar dividen yang besar (Prasetio dan Suryono, 2016).

$\mathrm{H}_{4}$ : Pengaruh Likuiditas, Profitabilitas, serta FCF secara silmutan pada Kebijakan Dividen

\section{METODE PENELITIAN}

Laporan tahunan BUMN yang menjual saham ke masyarakat yang terdaftar di Bursa Efek Indonesia (BEI) dipakai sebagai data sekunder dalam riset ini. Populasi riset ialah seluruh BUMN Go Public yang listing di BEI tahun 2015 - 2019 . Purposive sampling digunakan berdasarkan pada kriteria yaitu BUMN Go Public yang listing di BEI, membukukan profit serta sharing dividen periode 2015-2019. Akhirnya dipilih 11 BUMN Go Public selama 5 tahun, jadi total sampel sebesar 55 yang diperoleh dari www.idx.co.id. BUMN tersebut yaitu PT Bank Negara Indonesia Tbk, PT Bank Rakyat Indonesia Tbk, PT Bank Tabungan Negara Tbk, PT Bank Mandiri Tbk, PT Jasa Marga Tbk, PT Bukti Asam TBk, PT Semen Baturaja Tbk, PT Semen Indonesia Tbk, PT Telekomunikasi Indonesia Tbk, PT Wijaya Karya Tbk, dan PT Waskita Karya Tbk.

Kebijakan dividen merupakan variabel terikat dalam riset sekarang. Kebijakan dividen yaitu suatu keputusan dari perusahaan yang mau membayarkan dividen ke pemilik saham atau digunakan untuk investasi perusahaan. Ukuran kebijakan dividen yang dipakai adalah dividend payout ratio (DPR). Menurut Prastya (2019), DPR diukur:

$$
D P R=\frac{\text { Dividen per share }}{\text { Earning per share }}
$$

Likuiditas, profitabilitas, serta FCF digunakan sebagai variabel bebas pada riset sekarang. Likuiditas yaitu perbandingan yang mendeskripsikan kapasitas company dalam melunasi short term debt. Current Ratio (CR) dipakai dalam menilai likuiditas. Menurut Kasmir (2010:111) CR diukur:

$$
C R=\frac{\text { Current assets }}{\text { Current liabilitas }}
$$

Profitabilitas ialah rasio pengukuran yang mendeskripsikan company dalam memperoleh profit, salah satunya diperoleh dari penjualan. Profitabilitas diperoleh melalui Return on Assets (ROA). Ukuran ROA menurut Kasmir (2010: 115) adalah:

$$
R O A=\frac{\text { Net Income }}{\text { Total Asset }}
$$

Aliran kas bebas adalah deskripsi pertumbuhan, kinerja keuangan company. Saldo free cash flow $(F C F)$ yang berasal dari operation activities perusahaan yang bisa dipai guna pelunasan utang atau dividen payout. Rumus FCF yaitu:

FCF = Arus Kas Operasi - Belanja Modal

Adapun persamaan persamaan regresi linier yang dipakai: 


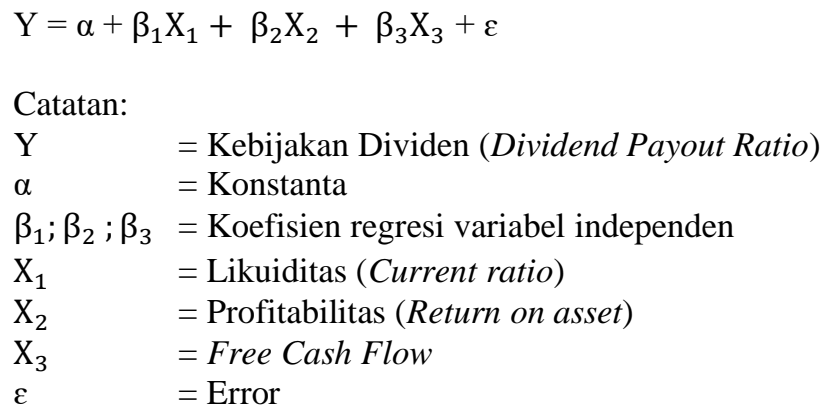

\section{HASIL DAN PEMBAHASAN}

\section{A. Hasil} dividen.

Pengujian hipotesis dengan analisis regresi berganda dilakukan untuk menguji variabel yang mempengaruhi kebijakan

Tabel 1

Uji Koefisien Determinasi

\begin{tabular}{|r|r|r|r|r|}
\hline \multicolumn{5}{|c|}{ Model Summary $^{\mathrm{b}}$} \\
\hline Model & $\mathrm{R}$ & \multicolumn{1}{|c|}{$\mathrm{R}^{2}$} & Adj. $\mathrm{R}^{2}$ & Std. Error of the Estimate \\
\hline 1 & $.382^{\mathrm{a}}$ & .146 & .095 & .32577 \\
\hline
\end{tabular}

a. Predictors: (Konstanta), FCF, CR, ROA

b. Variable terikat: DPR

Berdasarkan data dapat dijelaskan bahwa angka koefisien determinasi $\left(\mathrm{R}^{2}\right)$ sebesar 0,146 (14,6\%). Kebijakan dividen dipengaruhi oleh variabel likuiditas $\left(X_{1}\right)$, Profitabilitas $\left(X_{2}\right)$, serta FCF $\left(X_{3}\right)$. Pengujian selanjutnya dilakukan melalui pengujian statistik t sebagai berikut.

Tabel 2

Uji Statistik t

\begin{tabular}{|ll|r|r|r|r|r|}
\hline \multirow{2}{*}{ Model } & & \multicolumn{2}{|c|}{ Unstandardized Coefficients } & Standardized Coefficients & \multicolumn{1}{c|}{ T } & Sig. \\
\cline { 3 - 7 } & (Constant) & B & Std. Error & Beta & & \\
\hline 1 & .361 & .080 & & & 4.516 & .000 \\
& CR & -.053 & .045 & -.166 & -1.178 & .244 \\
& ROA & 2.756 & .957 & .437 & 2.880 & .006 \\
& FCF & .012 & .017 & .102 & .703 & .485 \\
\hline
\end{tabular}

Dijelaskan pada tabel 2 bahwa nilai signifikan likuiditas (CR) mempunyai angka signifikan sebanyak 0,244>0,05, maksudnya kebijakan dividen tidak dipengaruhi oleh variabel likuiditas. Profitabilitas (ROA) memiliki angka signifikan sebanyak $0,006<0,05$, maksudnya kebijakan dividen dipengaruhi signifikan oleh variabel profitabilitas. variabel FCF memiliki angka signifikan sebanyak 0,485 > 0,05, yang berarti variabel kebijakan dividen tidak dipengaruhi oleh FCF.

Tabel 3 menunjukkan nilai signifikan sebanyak $0,044<0,05$. Maknanya ada pengaruh secara simultan variabel likuiditas, profitabilitas, serta FCF pada kebijakan dividen.

Tabel 3

Uji Statistik F

ANOVA $^{\mathrm{b}}$

\begin{tabular}{|ll|r|r|r|r|r|}
\hline \multicolumn{1}{|c|}{ Model } & Sum of Squares & Df & Mean Square & F & Sig. \\
\hline 1 & Regresi & .923 & 3 & .308 & 2.899 & $.044^{\mathrm{a}}$ \\
& Residual & 5.412 & 51 & .106 & & \\
Total & 6.335 & 54 & & & \\
\hline
\end{tabular}

a. Prediktor: (Konstanta), FCF, CR, ROA

b. Variable Terikat: DPR 


\section{B. Pembahasan}

1. Likuiditas berpengaruh pada Kebijakan Dividen

Likuiditas dalam pengujian ini diperoleh nilai signifikan sebesar 0,244 dengan koefisien sebesar -1,178. Nilai 0,244 $>$ 0,05 dengan tanda koefisien minus, sehingga kesimpulan penelitian ini kebijakan dividen tidak dipengaruhi likuiditas. Maknanya hipotesis $1\left(\mathrm{H}_{1}\right)$ ditolak. Likuiditas menampilkan kapasitas perusahaan membiayai biaya operasional serta membayar utang jangka pendek. Analisis riset menunjukan bahwa pembayaran dividen tidak dipengaruhi besar-kecilnya likuiditas. Likuiditas perusahaan baik tidak berbanding lurus dengan baiknya pembayaran dividen.

Kesimpulan riset sekarang sejalan dengan riset Prastya (2019), Bilqis (2018), Tarwiyah (2018), serta Herwidodo (2012) yang menghasilkan kebijakan dividen tidak dipengaruhi oleh likuiditas. Likuiditas perusahaan tinggi yang bersumber dari keuntungan merupakan sumber harta perusahaan yang dapat dijadikan kas. Sumber pendapatan kas ini akan dipai untuk biaya oprasional, namun tidak dibayarkan menjadi deviden pada pemegang saham. Laba akan dioptimalisasi guna menunjang kelangsungan company.

2. Pengaruh Profitabilitas pada Kebijakan Dividen

Variabel profitabilitas dalam riset ini didapatkan angka signifikan sebesar 0,006 dengan koefisien sebesar 2,880. Angka signifikan 0,006 0,05 dengan arah koefisien positif, maka pada penelitian ini variabel profitabilitas berpengaruh pada kebijakan dividen. Kesimpulannya $\mathrm{H}_{2}$ diterima. Hasil riset menunjukkan kebijakan dividen dipengaruhi signifikan oleh profitabilitas. Artinya, banyak sedikitnya sharing dividen akan dipengaruhi oleh profitabilitas dari besar kecilnya laba perusahaan. Perusahaan harus berupaya meningkatkan labanya supaya pembagian dividen semakin besar pula. Stabilitas keuntungan perusahaan perlu dijaga agar mampu memberikan kepastian tingkat pembayaran dividen kepada pemilik saham.

Konsistensi pembayaran dividen menunjukkan bahwa perusahaan mempunyai prospek bagus. Pengumuman peningkatan dividen akan memberikan keyakinan kepada investor dan calon investor bahwa kondisi perusahaan sekarang dan prospek yang akan datang relatif bagus. Kesimpulan riset ini searah dengan hasil penelitian Prastya (2019), Tarwiyah (2018), serta Prasetio dan Suryono (2016) yang menyimpulkan bahwa kebijakan dividen dipengaruhi signifikan oleh profitabilitas. Kondisi tersebut karena semakin besar ROA, semakin besar pula sharing dividen kepada investor oleh perusahaan. ROA yang semakin tinggi mengindikasikan kinerja perusahaan tambah baik karena return yang makin tinggi. Kondisi tersebut seiring dengan teori sinyal yang menyebutkan bahwa manajemen perusahaan mau membagikan dividen sebagai signal kesuksesan perusahaan menghasilkan laba.

3. Pengaruh FCF pada Kebijakan Dividen

Variabel arus kas bebas dalam pengujian ini dihasilkan angka signifikan 0,485 dan koefisien sebesar 0,703. Angka signifikan 0,485 > 0,05 dengan arah koefisien positif, maka pada riset sekarang variabel arus kas bebas tidak mempengaruhi kebijakan dividen. Dengan demikian $\mathrm{H}_{3}$ tidak diterima. Hasil penelitian menunjukkan besar-kecilnya FCF tidak memberikan pengaruh pada tinggi-rendahnya pembayaran dividen. Apabila company mengharapkan peningkatan aset pemilik saham melalui pembagian dividen sedangkan keadaan FCF kecil, company bisa memakai sumber dana dari luar.

Kesimpulan riset variabel ini seiring dengan riset Prastya (2019), Suyono (2018), Nursafitri (2013), dan Herwidodo (2012) yang menyimpulkan kebijakan dividen tidak dipengaruhi oleh FCF. Hal ini karena FCF sekarang belum merupakan concern untuk investor di Indonesia. Kondisi tersebut karena perusahaan belum memberikan informasi tentang arus kas bebas secara tersurat sehingga belum memberikan pengaruh pada kebijakan dividen oleh perusahaan. Hal ini berkaitan dengan konflik keagenan. Agency problem terjadi sebab principal khawatir apabila company mempunyai arus kas bebas yang besar mau dipakai untuk resource non-efisien serta digunakan investasi yang tidak visible. Upaya meminimalkan cost agency dampak dari agency problem tersebut adalah membayar dividen pada pemilik saham.

4. Pengaruh likuiditas, profitabilitas, serta aliran kas bebas secara simultan pada kebijakan dividen.

Variabel likuiditas, profitabilitas, dan aliran kas bebas secara bersama-sama dalam pengujian tersebut menghasilkan angka signifikan 0,044 dengan koefisien 2,899. Angka signifikan 0,044 > 0,05 pada arah positif. Sehingga pada penelitian ini variabel likuiditas, profitabilitas, serta aliran kas bebas secara serempak dapat signifikan mempengaruhi kebijakan dividen. Dengan demikian hipotesis $4\left(\mathrm{H}_{4}\right)$ diterima. Kesimpulan pengujian variabel ini sama dengan hasil penelitian Nursafitri (2013) serta Herwidodo (2012) yang menyatakan, aliran kas bebas, profitabilitas, dan likuiditas mempengaruhi kebijakan dividen secara simultan.

\section{KESIMPULAN}

Kesimpulan hasil penelitian yaitu:

1. Kebijakan dividen tidak dipengaruhi signifikan oleh likuiditas.

2. Kebijakan dividen tidak dipengaruhi signifikan oleh profitabilitas.

3. Kebijakan dividen tidak dipengaruhi signifikan oleh free cash flow. 
4. Likuiditas, profitabilitas, dan FCF berpengaruh secara serempak signifikan pada kebijakan dividen.

Saran yang dapat diberikan:

1. Bagi manajemen perlu memperhatian kebijakan dividen, mulai dari upaya meningkatkan profitabilitas perusahaan guna menjaga konsistensi bahkan peningkatan pembayaran dividen.

2. Bagi para calon investor perlu melakukan analisis terhadap perusahaan terlebih dahulu, bagaimana dengan umur perusahaan, kestabilan usaha dan keuntungan yang berpengaruh pada sharing dividen kepada pemilik saham.

\section{DAFTAR PUSTAKA}

Bilqis, Hanna. 2018. Pengaruh Investment Opportunity Set, Likuiditas, Profitabilitas Dan Size (Ukuran Perusahaan) Terhadap Kebijakan Dividen. SKRIPSI. Jakarta: UIN Syarif Hidayatullah.

Riyanto, Bambang. 2010. Dasar-Dasar Pembelanjaan Perusahaan. Yogyakarta: BPFE.

Guinan, Jack. 2010. INVESTOPEDIA: Cara Mudah Memahami Istilah Investasi. Jakarta: Hikmah

Hanafi, Mamduh F. 2018. Manajemen Keuangan. Yogyakarta: BPFE.

Herwidodo, Gatot. 2012. Analisis Pengaruh FCF, Profitabilitas, Likuiditas, Leverage Serta Earning Per Share Terhadap Kebijakan Dividen Pada Perusahaan Manufaktur Tahun 2008-2011. SKRIPSI. Semarang: Universitas Dian Nuswantoro

Kasmir. 2010. Pengantar Manajemen Keuangan. Jakarta : Kencana Prenada Media Group.

Nursafitri, Diah. 2013. Pengaruh Free Cash Flow, Invetsment Opportunity Set (IOS) Dan Firm Size Terhadap Kebijakan Dividen Perusahaan Yang Terdaftar Di BEI Periode 2009-2011. SKRIPSI. Yogyakarta: UNY.

Prasetio, Djoko Adi dan Suryono, Bambang. 2016. Pengaruh Profitabilitas, FCF, Investment Opportunity Set Terhadap Dividend Payout Ratio. Jurnal Ilmu dan Riset Akuntansi: Volume 5, Nomor 1, Januari 2016.

Prastya, Andre Hand. 2019. Pengaruh FCF, Leverage, Profitabilitas, Likuiditas, Dan Ukuran Perusahaan Terhadap Kebijakan Dividen. SKRIPSI. Jakarta: Universitas Islam Negeri Syarif Hidayatullah.

Suyono, Nanang Agus. 2018. Faktor-Faktor Yang Mempengaruhi DPR Pada Perusahaan Perbankan Di BEI. Journal Of Economic, Management, Accounting And Technology Vol. 1, No. 1 Agustus 2018. Wonosobo: Universitas Sains Al Qur'an (UNSIQ)

Tarwiyah, Lailatut. 2018. Pengaruh Investment Opportunity Set, Leverage, Profitabilitas, Dan Likuiditas Terhadap Kebijakan Dividen. SKRIPSI. Malang: UIN Maulana Malik Ibrahim.

UU No. 19 tahun 2003 tentang BUMN

www.bps.go.id

www.idx.co.id 